\title{
ANALISIS PENGENDALIAN PERSEDIAAN SUKU CADANG PESAWAT B737-NG DENGAN PENDEKATAN MODEL PERIODIC REVIEW DI PT. X
}

\author{
Harwan Ahyadi ${ }^{1}$, Siti Khodijah ${ }^{2}$ \\ Program Studi Teknik Industri, Institut Sains dan Teknologi Nasional, Jakarta Selatan, Indonesia ${ }^{12}$ \\ email $^{1}$ : harwanfti@yahoo.co.id
}

\begin{abstract}
PT. $X$ is one of the companies engaged in the field of an aircraft-maintenance and repairing services. PT. $X$ classifies the aircraft spare parts into three groups namely rotable, repairable, and expandable. PT. $X$ has a problem of having shortage inventory of the expandable spare part with 9 unit total of shortage in 2016. If this problem occurs continuously, it can increase the total inventory cost. Therefore, this study discusses the improvement of the inventory control of the expandable spare parts.

The first phase of this study is forecasting the existing spare parts of the A Classes. Then, we determine the maximum inventory and the average inventory in warehouse using minmax method. After that, we determine the inventory level which covers ordering period $(T)$, maximum inventory $(R)$ and the average inventory in warehouse using Periodic Review Models. The final phase of this study is comparing the total inventory cost between Periodic Review Models and Min-Max method.

The Classification with $A B C$ method result 5 spare parts from A Class with a percentage of total items are $12.5 \%$ from 40 total item. Meanwhile, the total value of A Class amounted to $71.80 \%$ that had Rp 132,285,644.22 from the total price Rp 184,218,274.36. Periodic Review Models result an ordering period $(T)$ and maximum inventory $(R)$ which is optimal and can minimizes shortage 0 unit from 6 unit in A Class. With this decreased of shortage, it can minimizes the total inventory cost from the company. The comparative results between the total inventory cost using Periodic Review Models and Min-Max Method is Periodic Review Models has a smaller total inventory cost than Min-max Method with a total saving of inventory cost amounted $R p$ 81,121,836.62 and the percentage savings of $39.25 \%$.
\end{abstract}

Keywords: spare parts, inventory, min-max method.

\section{PENDAHULUAN}

\section{Latar Belakang}

Sebuah perusahaan yang bergerak dalam bidang jasa perawatan pesawat terbang yang biasa dikenal dengan MRO (Maintenance, Repair, dan Overhaul). Suku cadang yang dimiliki dalam kaitannya dengan MRO dikelompokkan menjadi 3 jenis, yaitu jenis rotable, repairable, dan expendable. Suku cadang yang sering mengalami permasalahan kekurangan persediaan(Shortage) adalah suku cadang jenis expendable.

Penelitian ini dilakukan pada suku cadang jenis expendable untuk pesawat tipe B737-NG. Jumlah Shortage 40 suku cadang jenis expendable yang diteliti pada tahun 2016 tercatat sebanyak 7 Suku Cadang yang mengalami shortage. Dimana shortage masing- masing suku cadang yaitu material 474031, material 002A0006-39, material 510183-401 material 305766-1 material E0400-01, material MS28782-19 sebanyak 1 item yang tidak terpenuhi, dan material MS20995C32 Banyaknya shortage ini, mengakibatkan keterlambatan penerbangan, karena pesawat harus menunggu diperbaiki sampai tersedianya suku cadang yang diperlukan di gudang. Keterlambatan penerbangan ini juga mengakibatkan kerugian bagi perusahaan.Kendala tersebut diatas, yang menjadikan fokus dalam penelitian.

Dengan harapan, penelitian ini diperoleh pengendalian persediaan yang lebih optimal, 
sehingga dapat meminimalkan total biaya persediaan.

Batasan masalah dalam penelitian adalah jenis suku cadang expendable yang terdapat di unit TME (Team Material Expendable), penelitian dilakukan dari bulan Oktober 2015 sampai dengan September 2016.

\section{TINJAUAN PUSTAKA}

\section{Suku Cadang Pesawat}

Persediaan suku cadang pesawat termasuk kategori persediaan material MRO, yaitu persediaan yang mendukung operasional proses maintenance. Suku cadang pesawat terbang dibagi menjadi 3, yaitu :

1) Rotable Material

2) Repairable Material

3) Expendable Material

Klasifikasi Persediaan Dengan Metode ABC

Kriteria-kriteria dalam klasifikasi ABC adalah sebagai berikut :

1) Kelas $A$ - Persediaan ini memiliki nilai volume tahunan rupiah yang tinggi. Kelas ini memiliki sekitar 70\% dari total nilai persediaan,

2) Kelas B - Persediaan ini mempunyai nilai volume tahunan rupiah yang menengah.

Kelompok ini merepresentasikan sekitar $20 \%$ dari total nilai persediaan

3) Kelas C - Persediaan ini memiliki nilai volume tahunan rupiah sekitar $10 \%$ dari total nilai persediaan,

\section{Peramalan Single Exponential Smoothing}

Persamaan yang dipakai dalam metode ini adalah :

$F_{t+1}=\alpha D_{t}+(1-\alpha) F_{t}$

Keterangan :

$F_{t+1}=$ Peramalan periode $\mathrm{t}+1$

$\alpha \quad=$ Konstanta Pemulusan ( nilainya antara 0 dan 1)

$D t \quad=$ Data Aktual Periode $\mathrm{t}$

$F t=$ Pemalan periode $\mathrm{t}$

Metode ini cocok untuk data stasioner. Kelebihan dari metode ini adalah tidak memerlukan data yang terlalu banyak dan dapat mengurangi masalah penyimpanan data.

\section{Pengukuran Kesalahan Peramalan dengan} MAD (Mean Absolute Deviation)

Perhitungan kesalahan peramalan dengan cara MAD dapat dirumuskan :

$$
\mathrm{MAD}=\frac{\sum\left(\mathrm{Dt}-\mathrm{F}_{\mathrm{t}}\right)}{\mathrm{n}}
$$

Keterangan :

Dt $=$ Permintaan Aktual

$\mathrm{Ft}=$ permintaan Hasil Peramalan

$\mathrm{n}=$ Jumlah periode

\section{Pengendalian Persediaan \\ Pengertian Persediaan;}

Persediaan adalah suatu bahan atau barang yang disimpan yang akan digunakan untuk memenuhi tujuan tertentu, misalnya untuk digunakan dalam proses produksi atau perakitan, untuk dijual kembali, atau untuk suku cadang dari suatu peralatan atau mesin. ${ }^{1)}$

\section{Tujuan Persediaan}

Kegiatan manajemen persediaan memiliki beberapa tujuan yang ingin dicapai, diantaranya yaitu :

a. Meminimalisasi nilai investasi pada persediaan.

b. Menciptakan penggunaan biaya yang efisien

\section{Biaya Dalam Persediaan}

1) Biaya pemesanan

Biaya pemesanan (ordering cost) dihtung

berdasarkan rumus:

$\mathrm{Op}=\mathrm{f} \times \mathrm{A}$

$\mathrm{f}=$ frekuensi pemesanan/tahun

A= Biaya tiap kali pemesanan

2) Biaya Penyimpanan

Biaya penyimpanan (holding cost) adalah biaya yang dikeluarkan berkenaan dengan diadakannya persediaan barang. Biaya penyimpanan dapat dinyatakan dalam bentuk rupiah per-tahun per-unit barang.

$\mathrm{Oh}=\%$ Harga per unit $\mathrm{x}$ Jumlah unit yang ada digudang......(4)

3) Biaya kekurangan persediaan

Biaya kekurangan persediaan (shortage cost, stock out cost) adalah biaya yang timbul sebagai akibat tidak tersedianya barang pada waktu diperlukan.

$\mathrm{Ok}=\%$ harga perunit $\mathrm{x}$ jumlah

Shortage.

\section{Metode Pengendalian Persediaan Min-Max}

Untuk material expendable menggunakan metode minimum maksimum level, dimana apabila jumlah persediaan sudah mencapai batas reorder point (ROP), maka dilakukan pembelian kembali.

Langkah-Langkah dalam menghitung pengendalian persediaan metode min-max, yaitu :

1) Menghitung frekuensi pemesanan dengan rumus :

$$
\mathrm{f}=\frac{\mathrm{D}}{\mathrm{Q}} \text {, . }
$$

Dimana nilai dari Q dapat dicari sebagai

berikut : $\mathrm{Q}=\sqrt{\frac{2 \times \mathrm{A} \times \mathrm{D}}{\mathrm{h}}}$,

Dimana :

$\mathrm{D}=$ Demand (Permintaan Selama Setahun)

$\mathrm{Q}=$ Jumlah tiap kali pesan

$\mathrm{A}=$ Biaya Pemesanan 
$\mathrm{h}=$ Biaya Penyimpanan

2) Menghitung Persediaan Maksimum :

a) Menghitung Safety Stock $\mathrm{SS}=$

$\underline{\text { Rata-rata pemakaian per bulan } x \text { Lead Time }}$

b) Menghitung minimum stock Min. Stock $=($ Rata-Rata Pemakaian $\mathrm{x}$ Lead Time)

c) Menghitung Reorder Point (ROP) $\mathrm{ROP}=$ Min + SS, ..

d) Menghitung Maksimum Stok Max. Stock $=($ ROP + Min $) x$ L,

3) Menghitung Rata-rata Persediaan di gudang selama setahun :

Rata-rata persediaan $=$ Max $-\mathrm{DL}$

Dimana :

$\mathrm{D}=$ Demand (Permintaan Selama Setahun)

4) Menghitung Prediksi Jumlah Shortage (Kekurangan) Selama Setahun :

$$
\frac{\text { Total Shortage } 2016}{\text { Jumlah Permintaan } 2016}=
$$

Prediksi Shortage 2017

Jumlah Permintaan 2017

5) Menghitung Total Biaya Persediaan selama setahun :

$\mathrm{Ot}=\mathrm{Oh}+\mathrm{Op}+\mathrm{Ok}$,

Dimana :

$\mathrm{Oh}=$ (biaya simpan $\mathrm{x}$ rata-rata persediaan $\mathrm{di}$ gudang)

$\mathrm{Op}=($ demand $/$ lot pemesanan $) \times$ biaya pemesanan

Ok $=($ Total Shortage stock $\mathrm{x}$ Biaya Shortage $)$

\section{Model Pengendalian Persediaan Periodic Review}

Dengan metode periodic review, status persediaan di gudang ditentukan pada interval yang teratur dan tetap, dan memesan order quantity yang dibutuhkan sampai mencapai level persediaan maksimum.

1) Model $(\mathbf{R}, \mathbf{s})$

a) Formulasi Model $P$

Berdasarkan ekspektasi, ongkos inventori total (OT) terdiri dari komponen ordering cost, holding cost, dan shortage cost. Berikut ini akan dijabarkan formulasinya, sehingga akan dapat ditentukan variabelvariabel keputusan yang akan dikendalikan yaitu $T$ dan $\mathrm{R}$ :

\section{1) Ordering Cost (Op)}

Ordering cost per tahun $(\mathrm{Op})$ dapat

dinyatakan sebagai berikut :

A (ongkos tiap kali pesan) $\times$ (frekuensi

pemesanan per tahun)

$\mathrm{Op}=\mathrm{A} \times \mathrm{f}$,
Jika setiap kali pemesanan dilakukan selang waktu $\mathrm{T}$, frekuensi pemesanan per tahun sebesar :

$\mathrm{f}=\frac{1}{\mathrm{~T}}$,

Dengan demikian ordering cost per tahun dapat diformulasikan sebagai berikut :

$$
\mathrm{Op}=\frac{\mathrm{A}}{\mathrm{T}} \text {, }
$$

\section{2) Holding cost (Oh)}

Holding cost per tahun (Oh) merupakan perkalian antara ekspektasi inventori per tahun $(m)$ dengan holding cost per unit per tahun $(h)$ atau :

$\mathrm{Oh}=\mathrm{m} \times \mathrm{h}$,

Dalam suatu siklus tertentu, inventori akan berada pada tingkat $(s+T D)$ di awal siklus pada tingkat (s) di akhir siklus, sehingga inventori ekspektasi harga adalah :

$\mathrm{m}=\mathrm{s}+\frac{\mathrm{TD}}{2}$

Dalam kasus backorder kekurangan inventori dapat dipenuhi kemudian, secara sistematis dengan backorder memungkinkan nilai s berharga negatif sehingga ekspektasi harga s adalah :

$\mathrm{S}=\mathrm{R}-\mathrm{DL}-\mathrm{TD}$

Dengan demikian diperoleh ekspektasi inventori (m) sebagai berikut :

$\mathrm{m}=R-D L-T D+\frac{T D}{2}$,

Untuk itu, dengan mensubstitusikan persamaan $\mathrm{m}$ ke dalam rumus awal Oh, maka didapatkan rumus untuk menghitung $\mathrm{Oh}$, yaitu :

$\mathrm{Oh}=\left(R-D L-\frac{T D}{2}\right) \times \mathrm{h}, \ldots \ldots$.

Keterangan :

$\mathrm{R}=$ ekspektasi persediaan maksimum

$\mathrm{DL}=$ Ekspektasi permintaan selama $\mathrm{L}$ periode

$\mathrm{T}=$ Interval Waktu Antar Pemesanan

$\mathrm{D}=$ Jumlah permintaan

$\mathrm{h}=$ biaya holding cost

3) Shortage cost (Ok)

Jika ongkos setiap unit kekurangan inventori sebesar $\mathrm{Cu}$ dan jumlah total kekurangan inventori selama satu tahun adalah $\mathrm{N}_{\mathrm{T}}$, shortage cost per tahun adalah :

$$
\mathrm{O}_{\mathrm{k}}=\mathrm{N}_{\mathrm{T}} \times \mathrm{Cu}
$$

Adapun harga NT dapat ditentukan sebagai perkalian antara jumlah siklus dalam satu tahun dengan jumlah kekurangan inventori untuk setiap siklus, maka :

$$
\mathrm{N}_{\mathrm{T}}=\frac{\mathrm{N}}{\mathrm{T}}
$$


Dengan demikian, Shortage Cost dapat dihitung dengan rumus :

$\mathrm{O}_{\mathrm{k}}=\frac{\mathrm{Cu} \times \mathrm{N}}{\mathrm{T}}$,

Keterangan :

Ok = Total Biaya Kekurangan Persediaan

$\mathrm{Cu}=$ Biaya Kekurangan Persediaan

$\mathrm{N}=$ Kemungkinan jumlah kekurangan inventori

$\mathrm{T}=$ Interval waktu antar pemesanan

b. Solusi dengan Metode Hadley-Within

Seperti pada model $Q$, cara pencarian solusi $T^{*}$ dan $R^{*}$ juga akan menggunakan metode Hadley-Within dengan cara sebagai berikut :

1) Menghitung nilai $T$ sebagai berikut :

$$
\mathrm{T}=\sqrt{\frac{2 \times \mathrm{A}}{\mathrm{Dh}}}
$$

2) Menghitung $\alpha$ sebagai berikut :

$$
\alpha=\frac{\mathrm{T} \times \mathrm{h}}{\mathrm{Cu}}
$$

3) Menghitung R (Persediaan Maksimum)

dimana nilai $R$ mencakup kebutuhan

selama $(T+L)$ periode dan dinyatakan

dengan :

$\mathrm{R}=\mathrm{D}(\mathrm{T}+\mathrm{L})+\mathrm{Z} \alpha \sqrt{T+L}$

4) Menghitung Kemungkinan terjadinya

Shortage :

$\mathrm{N}=\sigma_{D} \sqrt{T+L}\left(f_{(Z \alpha)}-\left(Z_{\alpha} \times \omega_{Z \alpha}\right)\right.$

Dimana :

$f_{(Z \alpha)}=$ NORMDIST $(Z \alpha, 0,1,0)$

$\omega_{Z \alpha}=$ NORMDIST $(Z \alpha, 0,1,0)-(Z \alpha(1-$

NORMDIST $(Z \alpha, 0,1,1))$

5) Menghitung Ot Periodic Review :

$\mathrm{Ot}=\frac{\mathrm{A}}{\mathrm{T}}+\left(\mathrm{R}-\mathrm{DL}-\frac{\mathrm{DT}}{2}\right) \mathrm{h}+\frac{\mathrm{Cu} \mathrm{N}}{\mathrm{T}}$

6) Ulangi mulai langkah 2 dengan menambah

$\mathrm{T}$ sebesar 0.005 dan pengurangan $\mathrm{T}$ sebesar 0.005. Hal ini dilakukan untuk mendapatkan Ot Optimal.

\section{METODE PENELITIAN DAN DATA}

Metode Penelitian

Proses penelitian dapat dilihat pada sajian gambar 3.1

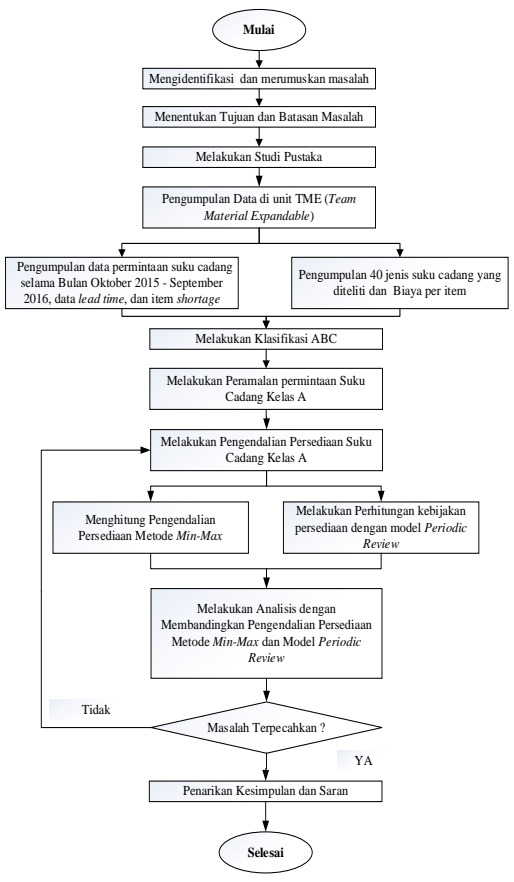

Gambar 3.1 Diagram Alir Penelitian

\section{Data permintaan}

Data permintaan material tipa bulan dapat dilihat dalam sajian tebel 3.1

\begin{tabular}{|c|c|c|c|c|c|c|}
\hline \multirow[b]{2}{*}{ No } & \multirow[b]{2}{*}{ Bulan } & \multicolumn{5}{|c|}{ Permintaan Material } \\
\hline & & $\begin{array}{c}4740 \\
31\end{array}$ & $\begin{array}{l}4011 \\
59-1\end{array}$ & $\begin{array}{l}\text { 002A0 } \\
\text { 006-39 }\end{array}$ & $\begin{array}{l}51018 \\
3-401\end{array}$ & $\begin{array}{l}3057 \\
66-1\end{array}$ \\
\hline 1 & Okt & 5 & 4 & 10 & 10 & 10 \\
\hline 2 & Nov & 6 & 4 & 8 & 9 & 10 \\
\hline 3 & Des & 5 & 5 & 10 & 10 & 10 \\
\hline 4 & Jan & 7 & 5 & 7 & 9 & 12 \\
\hline 5 & Feb & 5 & 3 & 8 & 8 & 8 \\
\hline 6 & Mar & 5 & 2 & 8 & 9 & 12 \\
\hline 7 & April & 5 & 5 & 10 & 10 & 10 \\
\hline 8 & Mei & 4 & 5 & 8 & 7 & 10 \\
\hline 9 & Juni & 5 & 5 & 10 & 9 & 10 \\
\hline 10 & Juli & 5 & 4 & 12 & 8 & 12 \\
\hline 11 & Agu & 6 & 4 & 9 & 8 & 14 \\
\hline 12 & Sept & 5 & 3 & 8 & 10 & 8 \\
\hline \multicolumn{2}{|c|}{ Total Demand } & 63 & 49 & 108 & 107 & 126 \\
\hline \multicolumn{2}{|c|}{ Rata-Rata } & 5 & 4 & 9 & 9 & 11 \\
\hline
\end{tabular}

Tabel 3.1 Data permintaan material perbulan

\subsection{Menghitung Holding Cost, Ordering Cost, dan Shortage Cost}

Holding cost Holding Material dapat dihitung berdasarkan rumus.(20),(25) untuk beberapa material dan dapat dilihat pada tabel 3.3, dan Orderingcost dapat dilihat pada tabel 3.4 
Tabel 3.2 Holding Cost/unit

\begin{tabular}{|l|l|l|l|}
\hline No & Material & $\begin{array}{l}\text { Harga } \\
\text { Rp/Unit }\end{array}$ & $\begin{array}{l}\text { Holding } \\
\text { Cost/Unit }\end{array}$ \\
\hline 1 & 474031 & 40640723,26 & 3657665,09 \\
\hline 2 & $401159-1$ & 31495288,34 & 2834575,95 \\
\hline 3 & 002 A0006-39 & $21,812,768.00$ & $1,963,149.12$ \\
\hline 4 & $510183-401$ & $20,247,000.00$ & $1,822,230.00$ \\
\hline 5 & $305766-1$ & $18,089,884.62$ & $1,628,089.62$ \\
\hline
\end{tabular}

Tabel 3.3 Ordering Cost/Order

\begin{tabular}{|l|l|l|l|}
\hline No & \multicolumn{1}{|c|}{ Material } & $\begin{array}{l}\text { Harga } \\
\text { Rp/Unit }\end{array}$ & $\begin{array}{l}\text { Holding } \\
\text { Cost/Unit }\end{array}$ \\
\hline 1 & 474031 & $40,640,723.26$ & $2,032,036.16$ \\
\hline 2 & $401159-1$ & $31,495,288.34$ & $1,574,764.42$ \\
\hline 3 & 002 A0006-39 & $21,812,768.00$ & $1,090,638.40$ \\
\hline 4 & $510183-401$ & $20,247,000.00$ & $1,012,350.00$ \\
\hline 5 & $305766-1$ & $18,089,884.62$ & $904,494.23$ \\
\hline
\end{tabular}

Tabel 3.4 Shortage Cost

\begin{tabular}{|l|l|l|l|}
\hline No & Material & $\begin{array}{l}\text { Harga } \\
\text { Rp/Unit }\end{array}$ & $\begin{array}{l}\text { Holding } \\
\text { Cost/Unit }\end{array}$ \\
\hline 1 & 474031 & $40,640,723.26$ & $4,064,072.33$ \\
\hline 2 & $401159-1$ & $31,495,288.34$ & $3,149,528.83$ \\
\hline 3 & 002 A0006-39 & $21,812,768.00$ & $2,181,276.80$ \\
\hline 4 & $510183-401$ & $20,247,000.00$ & $2,024,700.00$ \\
\hline 5 & $305766-1$ & $18,089,884.62$ & $1,808,988.46$ \\
\hline
\end{tabular}

\subsection{Peramalan Suku Cadang Kelas A}

Perhitungan Peramalan suku cadang dapat dilihat berdasarkan tabel 3.5

Tabel 3.5 Peramalan 2017

\begin{tabular}{|c|c|c|c|c|c|c|}
\hline \multirow{2}{*}{ No } & \multirow{2}{*}{ Bulan } & \multicolumn{5}{|c|}{ Permintaan Material } \\
\cline { 3 - 7 } & $\mathbf{3 1}$ & $\begin{array}{c}\mathbf{4 0 1 1} \\
\mathbf{5 9 - 1}\end{array}$ & $\begin{array}{c}\mathbf{0 0 2 A 0} \\
\mathbf{0 0 6}-39\end{array}$ & $\begin{array}{c}\mathbf{5 1 0 1 8} \\
\mathbf{3 - 4 0 1}\end{array}$ & $\begin{array}{c}\mathbf{3 0 5 7} \\
\mathbf{6 6 - 1}\end{array}$ \\
\hline 1 & Okt & 5 & 4 & 10 & 10 & 10 \\
\hline 2 & Nov & 5 & 4 & 10 & 10 & 10 \\
\hline 3 & Des & 6 & 4 & 10 & 10 & 10 \\
\hline 4 & Jan & 5 & 5 & 10 & 10 & 10 \\
\hline 5 & Feb & 7 & 5 & 10 & 10 & 12 \\
\hline 6 & Mar & 5 & 3 & 9 & 10 & 8 \\
\hline 7 & April & 5 & 2 & 9 & 10 & 12 \\
\hline 8 & Mei & 5 & 5 & 9 & 10 & 10 \\
\hline 9 & Juni & 4 & 5 & 9 & 9 & 10 \\
\hline 10 & Juli & 5 & 5 & 9 & 9 & 10 \\
\hline 11 & Agu & 5 & 4 & 10 & 9 & 12 \\
\hline 12 & Sept & 6 & 4 & 9 & 9 & 14 \\
\hline \multicolumn{2}{|l|}{ Total Demand } & 63 & 50 & 114 & 116 & 128 \\
\hline \multicolumn{2}{|l}{ Rata-Rata } & 5 & 4 & 10 & 10 & 11 \\
\hline
\end{tabular}

\subsection{Perhitungan Pengendalian Persediaan Metode Min-Max}

\section{a) Menghitung Frekuensi Pemesanan}

Frekuwensi pemesanan dapat dihitung berdasarkan rumus (6) dan dapat dilihat pada tabel 3.6 untuk setiap material
Tabel 3.6 Frekuensi Pemesanan

\begin{tabular}{|c|l|c|}
\hline No & \multicolumn{1}{|c|}{ Material } & $\begin{array}{c}\text { Frekuensi } \\
\text { Pemesanan }\end{array}$ \\
\hline 1 & 474031 & 8 \\
\hline 2 & $401159-1$ & 7 \\
\hline 3 & $002 \mathrm{~A} 0006-39$ & 10 \\
\hline 4 & $510183-401$ & 11 \\
\hline 5 & $305766-1$ & 11 \\
\hline
\end{tabular}

a. Menghitung Maksimum Stok Metode MinMax

1) Menghitung Safety Stock berdasarkan rumus II-(8). Diperoleh tiap material, disajikan dalam bentuk tabel 3.7.

Tabel 3.7.Safety Stock Metode Min-Max Tahun 2017

\begin{tabular}{|c|l|c|c|c|}
\hline No & Material & $\begin{array}{c}\text { Rata-rata } \\
\text { Pemakaian } \\
\text { per bulan }\end{array}$ & $\begin{array}{c}\text { Lead } \\
\text { time/ } \\
\text { Bulan }\end{array}$ & SS \\
\hline 1 & 474031 & 5 & 1 & 3 \\
\hline 2 & $401159-1$ & 4 & 1 & 2 \\
\hline 3 & $002 A 0006-39$ & 10 & 1 & 5 \\
\hline 4 & $510183-401$ & 10 & 1 & 5 \\
\hline 5 & $305766-1$ & 11 & 1 & 5 \\
\hline
\end{tabular}

2) Menghitung Minimum Stock

Perhitungan Minimum Stock metode minmax perusahaan diperoleh dan ditabelkan 3.8

Tabel 3.8 Minimum Stock Metode Min-Max Tahun 2017

\begin{tabular}{|c|l|c|c|c|}
\hline No & Material & $\begin{array}{c}\text { Rata-rata } \\
\text { Pemakaian } \\
\text { per bulan }\end{array}$ & $\begin{array}{c}\text { Lead } \\
\text { time/ } \\
\text { Bulan }\end{array}$ & $\begin{array}{c}\text { Minimum } \\
\text { Stock }\end{array}$ \\
\hline 1 & 474031 & 5 & 1 & 5 \\
\hline 2 & $401159-1$ & 4 & 1 & 4 \\
\hline 3 & $\begin{array}{l}002 \text { A0006- } \\
39\end{array}$ & 10 & 1 & 10 \\
\hline 4 & $\begin{array}{l}510183- \\
401\end{array}$ & 10 & 1 & 10 \\
\hline 5 & $305766-1$ & 11 & 1 & 11 \\
\hline
\end{tabular}

3) Menghitung Reorder Point

Reorder dihitung dan ditabelkan pada tabel 3.9 berdasarkan rumus II-(10)

Tabel 3.9 Reoder Point

\begin{tabular}{|c|l|c|c|c|c|}
\hline No & $\begin{array}{c}\text { Materia } \\
\mathbf{I}\end{array}$ & $\begin{array}{c}\text { Ma } \\
\boldsymbol{x} \\
\text { Stoc } \\
\boldsymbol{k}\end{array}$ & $\begin{array}{c}\text { Dema } \\
\mathbf{n d} \\
\mathbf{2 0 1 7}\end{array}$ & $\begin{array}{c}\mathbf{L T} \\
/ \mathbf{T a h u} \\
\mathbf{n}\end{array}$ & $\begin{array}{c}\text { Rata- } \\
\text { Rata } \\
\text { Persedia } \\
\text { an } \\
\text { Metode } \\
\text { Min-Max }\end{array}$ \\
\hline 1 & 474031 & 13 & 63 & 0.0822 & 8 \\
\hline 2 & $\begin{array}{l}401159- \\
1\end{array}$ & 10 & 50 & 0.0822 & 6 \\
\hline 3 & $\begin{array}{l}002 \mathrm{~A} 00 \\
06-39\end{array}$ & 25 & 114 & 0.0822 & 16 \\
\hline 4 & $\begin{array}{l}510183- \\
401\end{array}$ & 25 & 116 & 0.0822 & 15 \\
\hline 5 & $\begin{array}{l}305766- \\
1\end{array}$ & 27 & 128 & 0.0822 & 16 \\
\hline
\end{tabular}


Tabel 3.10 Reorder Point Metode Min-Max Tahun 2017

\begin{tabular}{|c|l|c|c|c|}
\hline No & Material & $\begin{array}{l}\text { Minimum } \\
\text { Stock }\end{array}$ & SS & $\begin{array}{c}\text { Reorder } \\
\text { Point }\end{array}$ \\
\hline 1 & 474031 & 5 & 3 & 8 \\
\hline 2 & $401159-1$ & 4 & 2 & 6 \\
\hline 3 & $\begin{array}{l}002 A 0006- \\
39\end{array}$ & 10 & 5 & 15 \\
\hline 4 & $\begin{array}{l}510183- \\
401\end{array}$ & 10 & 5 & 15 \\
\hline 5 & $305766-1$ & 11 & 5 & 16 \\
\hline
\end{tabular}

4) Maximum stock dihitung berdasarkan rumus II.-(11) Dan ditabelkan 3.11

Tabel 3.11 Maximum Stock Metode Min-Max Tahun

\begin{tabular}{|c|c|c|c|c|c|}
\hline No & Material & ROP & $\begin{array}{c}\text { Min } \\
\text { Stock }\end{array}$ & LT & $\begin{array}{c}\text { Max } \\
\text { Stock }\end{array}$ \\
\hline 1 & 474031 & 8 & 5 & 1 & 13 \\
\hline 2 & $401159-1$ & 6 & 4 & 1 & 10 \\
\hline 3 & $\begin{array}{c}002 A 0006- \\
39\end{array}$ & 15 & 10 & 1 & 25 \\
\hline 4 & $\begin{array}{c}510183- \\
401\end{array}$ & 15 & 10 & 1 & 25 \\
\hline 5 & $305766-1$ & 16 & 11 & 1 & 27 \\
\hline
\end{tabular}

b. Menghitung Rata-Rata Persediaan Tahun 2017 dengan Metode Min-Max

Berikut adalah contoh perhitungan rata-rata persediaan selama setahun di gudang metode min-max perusahaan berdasarkan rumus II.-(11)

Tabel 3.12 Rata-rata persediaan pertahun digudang Tahun 2017

\begin{tabular}{|l|l|l|l|l|c|}
\hline No & Material & $\begin{array}{c}\text { Max } \\
\text { Stock }\end{array}$ & $\begin{array}{c}\text { Dema } \\
\text { nd } \\
\mathbf{2 0 1 7}\end{array}$ & $\begin{array}{c}\text { LT } \\
/ \text { Tahu } \\
\mathbf{n}\end{array}$ & $\begin{array}{c}\text { Rata-Rata } \\
\text { Persediaan } \\
\text { Metode } \\
\text { Min-Max }\end{array}$ \\
\hline 1 & 474031 & 13 & 63 & 0.0822 & 8 \\
\hline 2 & $401159-1$ & 10 & 50 & 0.0822 & 6 \\
\hline 3 & $\begin{array}{l}002 \mathrm{~A} 000 \\
6-39\end{array}$ & 25 & 114 & 0.0822 & 16 \\
\hline 4 & $\begin{array}{l}510183- \\
401\end{array}$ & 25 & 116 & 0.0822 & 15 \\
\hline 5 & $305766-1$ & 27 & 128 & 0.0822 & 16 \\
\hline
\end{tabular}

\section{c. Menghitung Prediksi Shortage}

Berikut adalah contoh perhitungan Prediksi Shortage selama setahun metode min-max perusahaan dapat dilihat pada tabel 3.13

Tabel 3.13 Prediksi shortage stock

\begin{tabular}{|c|c|c|c|c|c|}
\hline $\begin{array}{c}\text { N } \\
\mathbf{0}\end{array}$ & $\begin{array}{c}\text { Mater } \\
\text { ial }\end{array}$ & $\begin{array}{c}\text { Dema } \\
\text { nd } \\
\mathbf{2 0 1 6}\end{array}$ & $\begin{array}{c}\text { Shorta } \\
\text { ge } \\
\text { Stock } \\
\mathbf{2 0 1 6}\end{array}$ & $\begin{array}{c}\text { Dema } \\
\text { nd } \\
\mathbf{2 0 1 7}\end{array}$ & $\begin{array}{c}\text { Predik } \\
\text { si } \\
\text { Shorta } \\
\text { ge } \\
\text { Stock } \\
\mathbf{2 0 1 7}\end{array}$ \\
\hline 1 & $\begin{array}{c}47403 \\
1\end{array}$ & 63 & 2 & 63 & 2 \\
\hline 2 & $\begin{array}{c}40115 \\
9-1\end{array}$ & 49 & 0 & 50 & 0 \\
\hline 3 & $\begin{array}{c}002 \mathrm{~A} 0 \\
006- \\
39\end{array}$ & 108 & 2 & 114 & 2 \\
\hline 4 & $\begin{array}{c}51018 \\
3-401\end{array}$ & 107 & 1 & 116 & 1 \\
\hline 5 & $\begin{array}{c}30576 \\
6-1\end{array}$ & 126 & 1 & 128 & 1 \\
\hline
\end{tabular}

a. Total Biaya Persediaan Metode Min-max

Berikut adalah contoh Total Biaya Persediaan (Ot) selama setahun metode min-max perusahaan dapat dilihat pada tabel 3.14

Tabel 3.14 Total Biaya Persediaan Metode Min-Max

\begin{tabular}{|c|c|c|c|c|c|}
\hline $\begin{array}{c}\text { N } \\
\mathbf{0}\end{array}$ & $\begin{array}{c}\text { Materi } \\
\text { al } \\
\text { rata } \\
\text { Persedi } \\
\text { aan } \\
\mathbf{2 0 1 7}\end{array}$ & $\mathbf{f}$ & $\begin{array}{c}\text { Sh } \\
\boldsymbol{r t}\end{array}$ & $\begin{array}{c}\text { Total Biaya } \\
\text { Persediaan } \\
\text { selama tahun } \\
\mathbf{2 0 1 7} \text { Rp }\end{array}$ \\
\hline 1 & 474031 & 8 & 8 & 2 & $53,645,754.66$ \\
\hline 2 & $\begin{array}{c}401159 \\
-1\end{array}$ & 6 & 7 & 0 & $28,030,806.64$ \\
\hline 3 & $\begin{array}{c}002 \mathrm{~A} 0 \\
006-39\end{array}$ & 16 & 10 & 2 & $46,679,323.52$ \\
\hline 4 & $\begin{array}{c}510183 \\
-401\end{array}$ & 15 & 11 & 1 & $40,494,000.00$ \\
\hline 5 & $\begin{array}{c}305766 \\
-1\end{array}$ & 16 & 11 & 1 & $37,807,858.91$ \\
\hline \multicolumn{7}{|c}{ TOTAL BIAYA PERSEDIAAN (Ot) } & $\begin{array}{l}206,657,743.7 \\
3\end{array}$ \\
\hline
\end{tabular}

\section{Pengendalian Persediaan Model Periodic Review}

\section{a. Menghitung Standar Deviasi}

Berikut adalah contoh perhitungan standar deviasi tahun 2017 Model Periodic Review :

1) Standar Deviasi Material 474031

$$
=\sqrt{\frac{(12 \times 2 a 7)-2,969}{12(12-1)}}=0.754
$$

Tabel 3.15 Hasil Standar Deviasi permintaan peramalan 2017

\begin{tabular}{|c|c|c|c|c|}
\hline & Material & $\sum \mathbf{D}^{\mathbf{2}}$ & $\left(\sum \mathbf{D}\right)^{\mathbf{2}}$ & $\begin{array}{c}\text { Standar } \\
\text { Deviasi } \\
\text { Permin } \\
\text { taan } \\
\mathbf{2 0 1 7}\end{array}$ \\
\hline 1 & 474031 & 337 & 3969 & 0.754 \\
\hline 2 & $401159-1$ & 218 & 2500 & 0.937 \\
\hline 3 & $\begin{array}{c}002 \mathrm{~A} 0006 \\
-39\end{array}$ & 1086 & 12996 & 0.522 \\
\hline 4 & $\begin{array}{c}510183- \\
401\end{array}$ & 1124 & 13456 & 0.492 \\
\hline 5 & $305766-1$ & 1392 & 16384 & 1.557 \\
\hline
\end{tabular}

a. Penentuan Periode Waktu antar pemesanan (T)

Berikut adalah contoh perhitungan interval pemesanan tahun 2017 Model Periodic Review:

1) Interval Pemesanan (T) Material 474031

$$
=\sqrt{\frac{2 \times \mathrm{Rp} 2,032,036.16}{63 \times \mathrm{Rp} 3,657,665.09}}=0.1328 / \text { tahun }
$$

Tabel 3.16 Interval Pemesanan (T) Tahun 2017 Model Periodic Review

\begin{tabular}{|c|c|c|c|c|c|}
\hline No & $\begin{array}{c}\text { Materi } \\
\text { al }\end{array}$ & $\begin{array}{c}\text { Biaya } \\
\text { Pemesan } \\
\text { an } \\
\text { (A) }\end{array}$ & $\begin{array}{c}\text { Dmnd } \\
\mathbf{2 0 1 7}\end{array}$ & $\begin{array}{c}\text { Biaya } \\
\text { Penyimp } \\
\text { anan } \\
\text { (h) }\end{array}$ & $\begin{array}{c}\text { Interval } \\
\text { Pemesan } \\
\text { an/ } \\
\text { Tahun }\end{array}$ \\
\hline 1 & 474031 & $\begin{array}{c}\text { Rp2,032, } \\
036.16\end{array}$ & 63 & $\begin{array}{c}\text { pp3,657, } \\
665.09\end{array}$ & 0.1328 \\
\hline 2 & $\begin{array}{c}401159 \\
-1\end{array}$ & $\begin{array}{c}\text { Rp1,574, } \\
764.42\end{array}$ & 50 & $\begin{array}{c}\text { Rp2,834, } \\
575.95\end{array}$ & 0.1491 \\
\hline 3 & $\begin{array}{c}002 \mathrm{~A} 0 \\
006-39\end{array}$ & $\begin{array}{c}\text { Rp1,090, } \\
638.40\end{array}$ & 114 & $\begin{array}{c}\text { Rp1,963, } \\
149.12\end{array}$ & 0.0987 \\
\hline 4 & $\begin{array}{c}510183 \\
-401\end{array}$ & $\begin{array}{c}\text { Rp1,012, } \\
350.00\end{array}$ & 116 & $\begin{array}{c}\text { Rp1,822, } \\
230.00\end{array}$ & 0.0979 \\
\hline 5 & $\begin{array}{c}305766 \\
-1\end{array}$ & $\begin{array}{c}\text { Rp904,49 } \\
4.23\end{array}$ & 128 & $\begin{array}{c}\text { Rp1,628, } \\
089.62\end{array}$ & 0.0932 \\
\hline
\end{tabular}




\section{b. Menghitung R (Maksimum Stok)}

1) Menghitung nilai $\alpha$

Berikut adalah contoh perhitungan $\alpha$ tahun 2017 Model Periodic Review:

Nilai $\alpha$ Material 47403

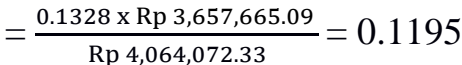

2) Menghitung Nilai R (Maksimum Stok)

Berikut adalah contoh perhitungan

Maksimum Stok tahun 2017 Model Periodic Review :

a) Maksimum Stok (R) Material 47403 $: \mathrm{R}=63(0.1328+0.0822)$

b) $+1.18 \sqrt{0.1328+0.0822}=14$ item

Tabel 3.18 Hasil Maksimum Stok dengan Periodic

\begin{tabular}{|c|c|c|c|c|c|c|c|c|}
\hline No & Mat & $\sigma_{z}$ & $\mathbf{T}$ & $\mathbf{L}$ & $\begin{array}{c}\mathbf{Z} \\
\boldsymbol{x}\end{array}$ & $\mathrm{f}_{\mathbf{z} \mathbf{s}}$ & $\boldsymbol{\omega}_{\mathbf{z} \mathbf{z}}$ & $\begin{array}{c}\text { Prediksi } \\
\text { Shortage } \\
\mathbf{2 0 1 7}(\mathbf{N})\end{array}$ \\
\hline 1 & $\begin{array}{c}4740 \\
31\end{array}$ & $\begin{array}{c}0.75 \\
4\end{array}$ & $\begin{array}{c}0.132 \\
8\end{array}$ & $\begin{array}{c}0.08 \\
22\end{array}$ & $\begin{array}{c}1 . \\
18\end{array}$ & $\begin{array}{c}0.19 \\
95\end{array}$ & $\begin{array}{c}0.05 \\
88\end{array}$ & 0.045541 \\
\hline 2 & $\begin{array}{c}4011 \\
59-1\end{array}$ & $\begin{array}{c}0.93 \\
7\end{array}$ & $\begin{array}{c}0.149 \\
1\end{array}$ & $\begin{array}{c}0.08 \\
22\end{array}$ & $\begin{array}{c}1 . \\
11\end{array}$ & $\begin{array}{c}0.21 \\
62\end{array}$ & $\begin{array}{c}0.06 \\
77\end{array}$ & 0.063687 \\
\hline 3 & $\begin{array}{c}002 \mathrm{~A} \\
0006\end{array}$ & $\begin{array}{c}0.52 \\
2\end{array}$ & $\begin{array}{c}0.098 \\
7\end{array}$ & $\begin{array}{c}0.08 \\
22\end{array}$ & $\begin{array}{c}1 . \\
35\end{array}$ & $\begin{array}{c}0.16 \\
08\end{array}$ & $\begin{array}{c}0.04 \\
11\end{array}$ & 0.023427 \\
\hline 4 & $\begin{array}{c}5101 \\
83- \\
401\end{array}$ & $\begin{array}{c}0.49 \\
2\end{array}$ & $\begin{array}{c}0.097 \\
9\end{array}$ & $\begin{array}{c}0.08 \\
22\end{array}$ & $\begin{array}{c}1 . \\
35\end{array}$ & $\begin{array}{c}0.15 \\
98\end{array}$ & $\begin{array}{c}0.04 \\
07\end{array}$ & 0.021897 \\
\hline 5 & $\begin{array}{c}3057 \\
66-1\end{array}$ & $\begin{array}{c}1.55 \\
7\end{array}$ & $\begin{array}{c}0.093 \\
2\end{array}$ & $\begin{array}{c}0.08 \\
22\end{array}$ & $\begin{array}{c}1 . \\
38\end{array}$ & $\begin{array}{c}0.15 \\
40\end{array}$ & $\begin{array}{c}0.03 \\
83\end{array}$ & 0.065936 \\
\hline
\end{tabular}

a. Rata-rata Persediaan Selama Tahun 2017 Model Periodic Review

Berikut adalah contoh perhitungan Rata-rata persediaan selama tahun 2017 Model Periodic Review :

1) Rata-Rata Persediaan digudang Selama Setahun Material 474031:

$$
=\left(14-(63 \times 0.0822)-\left(\frac{6 \mathrm{a} \times 0.1328}{2}\right)\right)=5
$$
item

Tabel 19 Rata-rata Persediaan

\begin{tabular}{|c|c|c|c|c|c|}
\hline No & $\begin{array}{c}\text { Mater } \\
\text { ial }\end{array}$ & $\begin{array}{c}\text { Biaya } \\
\text { Pemesana } \\
\mathbf{n} \\
\text { (A) }\end{array}$ & $\begin{array}{c}\text { Dmnd } \\
\mathbf{2 0 1 7}\end{array}$ & $\begin{array}{c}\text { Biaya } \\
\text { Penyimpan } \\
\text { an } \\
\text { (h) }\end{array}$ & $\begin{array}{c}\text { Interval } \\
\text { Pemesan } \\
\text { an/ } \\
\text { Tahun }\end{array}$ \\
\hline 1 & $\begin{array}{c}47403 \\
1\end{array}$ & $\begin{array}{c}\text { Rp2,032,03 } \\
6.16\end{array}$ & 63 & $\begin{array}{c}\text { Rp3,657,66 } \\
5.09\end{array}$ & 0.1328 \\
\hline 2 & $\begin{array}{c}40115 \\
9-1\end{array}$ & $\begin{array}{c}\mathrm{Rp} 1,574,76 \\
4.42\end{array}$ & 50 & $\begin{array}{c}\mathrm{Rp} 2,834,57 \\
5.95\end{array}$ & 0.1491 \\
\hline 3 & $\begin{array}{c}002 \mathrm{~A} 0 \\
006-39\end{array}$ & $\begin{array}{c}\mathrm{Rp} 1,090,63 \\
8.40\end{array}$ & 114 & $\begin{array}{c}\mathrm{Rp} 1,963,14 \\
9.12\end{array}$ & 0.0987 \\
\hline 4 & $\begin{array}{c}51018 \\
3-401\end{array}$ & $\begin{array}{c}\mathrm{Rp} 1,012,35 \\
0.00\end{array}$ & 116 & $\begin{array}{c}\mathrm{Rp} 1,822,23 \\
0.00\end{array}$ & 0.0979 \\
\hline 5 & 30576 & $\mathrm{Rp} 904,494$. & 128 & $\mathrm{Rp} 1,628,08$ & 9.62 \\
$2-1$ & 23 & & \multicolumn{3}{|c|}{0.0932} \\
\hline
\end{tabular}

Tabel 3.20 Rata-rata persediaan selama tahun 2017 model Periodic Review

\begin{tabular}{|c|c|c|c|c|c|c|}
\hline $\begin{array}{c}\mathbf{N} \\
\mathbf{0}\end{array}$ & Material & $\mathbf{R}$ & $\mathbf{D}$ & $\begin{array}{c}\text { L/ } \\
\text { Tahun }\end{array}$ & $\mathbf{T}$ & $\begin{array}{c}\text { Rata-Rata Model } \\
\text { Periodic Review }\end{array}$ \\
\hline 1 & 474031 & 14 & 63 & 0.0822 & 0.1328 & 5 \\
\hline 2 & $401159-1$ & 12 & 50 & 0.0822 & 0.1491 & 4 \\
\hline 3 & $\begin{array}{c}002 \mathrm{~A} 000 \\
6-39\end{array}$ & 21 & 114 & 0.0822 & 0.0987 & 6 \\
\hline 4 & $\begin{array}{c}510183- \\
401\end{array}$ & 21 & 116 & 0.0822 & 0.0979 & 6 \\
\hline 5 & $305766-1$ & 23 & 128 & 0.0822 & 0.0932 & 7 \\
\hline
\end{tabular}

b. Kemungkinan Shortage (N) Model Periodic Review

Berikut adalah contoh perhitungan Kemungkinan Shortage selama tahun 2017 Model Periodic Review :

1) Kemungkinan Shortage Material 474031:

$$
\begin{aligned}
\mathrm{N}= & 0.754 \sqrt{0.1328+0.0822}(0.1995- \\
& (1.18 \times 0.0588)) \\
= & 0.045541 \text { item }
\end{aligned}
$$

Tabel 3.21 Hasil Kemungkinan Shortage Tahun 2017 Periodic Review

\begin{tabular}{|c|c|c|c|c|}
\hline No & Material & $\begin{array}{c}\text { Shortage Cost } \\
(\mathbf{C u})\end{array}$ & $\boldsymbol{\alpha}$ & $\mathbf{Z} \boldsymbol{\alpha}$ \\
\hline 1 & 474031 & $\mathrm{Rp} 4,064,072.33$ & 0.1195 & 1.18 \\
\hline 2 & $401159-1$ & $\mathrm{Rp} 3,149,528.83$ & 0.1342 & 1.11 \\
\hline 3 & $002 \mathrm{~A} 0006-39$ & $\mathrm{Rp} 2,181,276.80$ & 0.0889 & 1.35 \\
\hline 4 & $510183-401$ & $\mathrm{Rp} 2,024,700.00$ & 0.0881 & 1.35 \\
\hline 5 & $305766-1$ & $\mathrm{Rp} 1,808,988.46$ & 0.0839 & 1.38 \\
\hline
\end{tabular}

\section{a. Total Biaya Persediaan Model Periodic} Review

Berikut adalah contoh perhitungan Total Biaya Persediaan Optimal (Ot) selama tahun 2017 Model Periodic Review :

Perhitungan Total Biaya Biaya Persediaan Optimal Material 474031 :

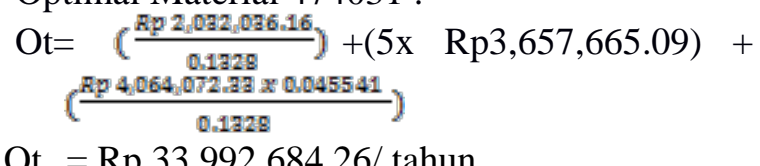

Ot $=$ Rp 33,992,684.26/ tahun

Tabel 3.22 Total Biaya Persediaan Optimal Periodic Review

\begin{tabular}{|c|c|c|c|c|c|}
\hline No & $\begin{array}{c}\text { Materi } \\
\text { al }\end{array}$ & $\begin{array}{c}\text { Rata- } \\
\text { Rata } \\
\text { Persedi } \\
\text { aan } \\
\mathbf{2 0 1 7}\end{array}$ & $\mathbf{T}$ & $\mathbf{N}$ & $\begin{array}{c}\text { Total Biaya } \\
\text { Persediaan } \\
\text { Periodic Review } \\
\text { Tahun 2017 } \\
\text { Rp }\end{array}$ \\
\hline 1 & 474031 & 5 & 0.1328 & 0.045541 & $33,992,684.26$ \\
\hline 2 & $\begin{array}{c}401159- \\
1\end{array}$ & 4 & 0.1491 & 0.063687 & $23,982,132.00$ \\
\hline 3 & $\begin{array}{c}002 A 00 \\
06-39\end{array}$ & 6 & 0.0987 & 0.023427 & $23,737,604.85$ \\
\hline 4 & $\begin{array}{c}510183- \\
401\end{array}$ & 6 & 0.0979 & 0.021897 & $22,186,561.89$ \\
\hline 5 & $\begin{array}{c}305766- \\
1\end{array}$ & 7 & 0.0932 & 0.065936 & $21,636,924.11$ \\
\hline \multicolumn{7}{|c|}{ TOTAL BIAYA PERSEDIAAN (Ot) } & $125,535,907.12$ \\
\hline
\end{tabular}




\section{ANALISIS}

\subsection{Klasifikasi ABC}

Berikut disajikan grafik pengklasifikasian Suku Cadang berdasarkan harga unit suku cadang dari masing-masing klas yang dapat dilihat pada sajian gambar 4.1

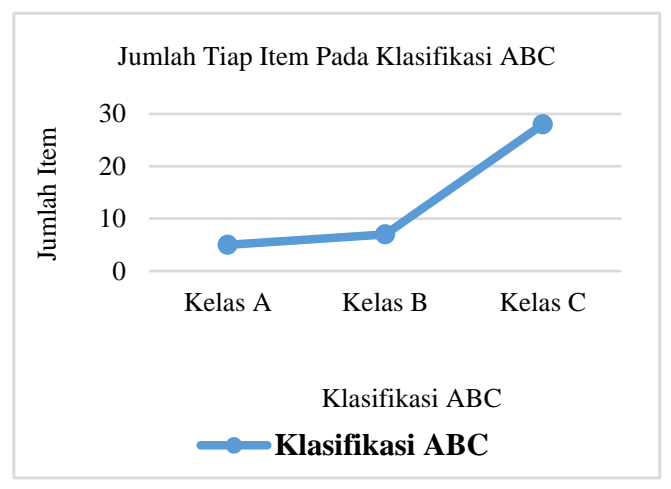

Gambar 4.1 Grafik Jumlah Item Pada MasingMasing Kelas

Berdasarkan gambar 4.1 diatas, maka dapat diketahui bahwa kelas A memiliki jumlah persentase sebanyak 71.81\%, Klas B 21,40\% dan klas C 6,79 \% dari total harga keseluruhan, dengan suku cadang kelas A memiliki harga pembelian sebanyak 5 item dengan persentase sebesar $12.5 \%$

Kelas B memiliki jumlah persentase sebanyak B dengan jumlah 7 unit dengan persentase sebesar $17.5 \%$, dan klas C 28 item dengan persentase sebesar $70 \%$ dari total item yang diteliti.

Untuk itu, dengan melakukan klasifikasi ABC ini, maka dalam menentukan pengendalian persediaan dapat difokuskan pada item-item yang bernilai besar yang masuk kategori A karena akan mengakibatkan kerugian yang besar bagi perusahaan.

\subsection{Peramalan Permintaan}

Dari berbagai suku cadang yang diperoleh harga MAD berurut Suku Cadang 474031 dengan konstanta $\alpha$ yaitu 0.9, Berikut hasil permalan satu dilihat bahwa hasil peramalan menunjukkan permintaan yang lebih stabil pada bulan Oktober, November, April, Mei, dan Agustus. Hal ini berbeda dengan tahun sebelumnya dimana permintaan stabil hanya terjadi pada 4 bulan yaitu Oktober, Maret, April, dan Juli. Dimana peramalan dilakukan dengan metode single exponential smoothing .

Untuk Suku Cadang 401159-1 nilai konstanta $\alpha$ yang digunakan yaitu 0.9 , sehingga memiliki MAD yang paling kecil.Menunjukkan permintaan yang lebih stabil pada bulan Oktober, November, Desember, Februari, Juni, Juli, dan September. Hal ini berbeda dengan tahun sebelumnya dimana permintaan stabil hanya terjadi pada 6 bulan yaitu Oktober, November, Januari, Mei, Juni, dan Agustus.

Suku Cadang 002A0006-39 dengan nilai konstanta $\alpha$ yang digunakan yaitu 0.1 , hal tersebut dikarenakan nilai $\alpha$ ini memiliki MAD yang paling kecil. Berikut hasil permalan satu tahun kedepan suku cadang 0020006-39 dengan $\alpha=0.1$ dapat dilihat pada sajian gambar 4.2.

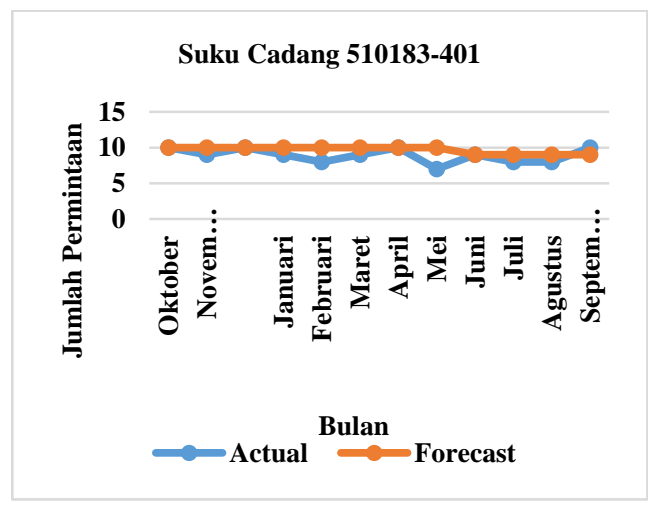

Gambar 4.2 Grafik Permintaan Aktual dengan peramalan spare part 002A0006-39

Pada gambar diatas dapat dilihat bahwa hasil peramalan menunjukkan permintaan yang lebih konstan dibanding tahun sebelumnya. Dimana perimintaan peramalan cenderung konstan pada bulan Oktober, November, Desember, Januari, Februari, April, Mei, Juni, dan Juli.

Hasil peramalan ini cenderung konstan karena peramalan dilakukan dengan metode single exponential smoothing yang memiliki nilai $\alpha=$ 0.1 . Nilai $\alpha$ sebesar 0.1 yang dihasilkan memiliki jumlah peramalan yang jauh lebih tinggi dibandingkan dengan data aktual yang ada. Hal ini juga terlihat dari pola permintaan data aktual dimana permintaan tidak berfluktuasi atau relatif stabil dari waktu ke waktu.

Untuk Suku Cadang 510183-401 dengan nilai konstanta $\alpha$ yang digunakan yaitu 0.1, hal tersebut dikarenakan nilai $\alpha$ ini memiliki MAD dengan $\alpha=0.1$ dapat dilihat pada sajian gambar 4.3.

dengan peramalan spare part 510183-401

Pada gambar diatas dapat dilihat bahwa hasil peramalan menunjukkan permintaan yang lebih konstan dibanding tahun sebelumnya. Dimana permintaan peramalan cenderung konstan pada bulan Oktober, November, Desember, Januari, Februari, Maret, April, Mei, Juli, Agustus, dan September. 


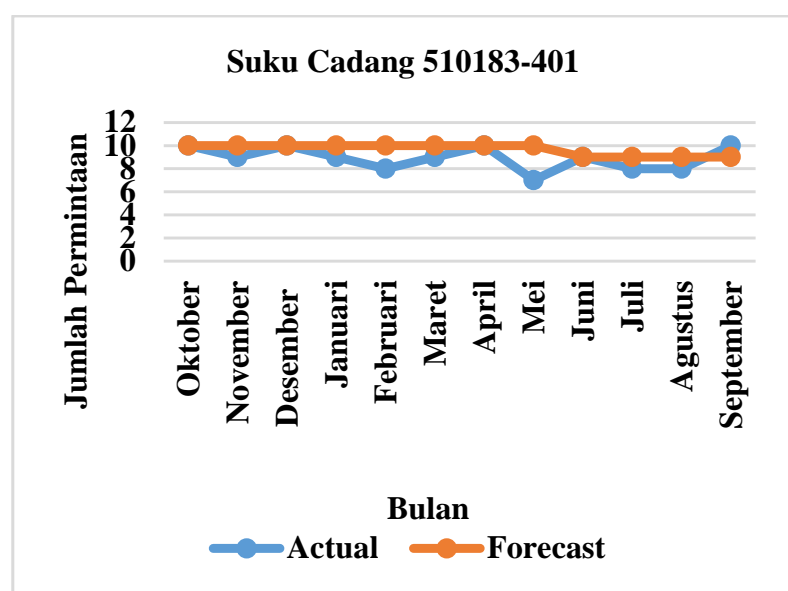

Gambar 4.3 Grafik Permintaan Aktual

Hasil peramalan ini cenderung konstan karena peramalan dilakukan dengan metode single exponential smoothing yang memiliki nilai $a=$ 0.1 . Nilai $\alpha$ sebesar 0.1 yang dihasilkan memiliki jumlah peramalan yang jauh lebih tinggi dibandingkan dengan data aktual yang ada. Hal ini juga terlihat dari pola permintaan data aktual dimana permintaan tidak berfluktuasi atau relatif stabil dari waktu ke waktu.

Suku Cadang 305766-1 dengan nilai konstanta $\alpha$ yang digunakan yaitu 0.9, hal tersebut dikarenakan nilai $\alpha$ ini memiliki MAD dengan $\alpha$ $=0.9$ dapat dilihat pada sajian gambar 4.4.

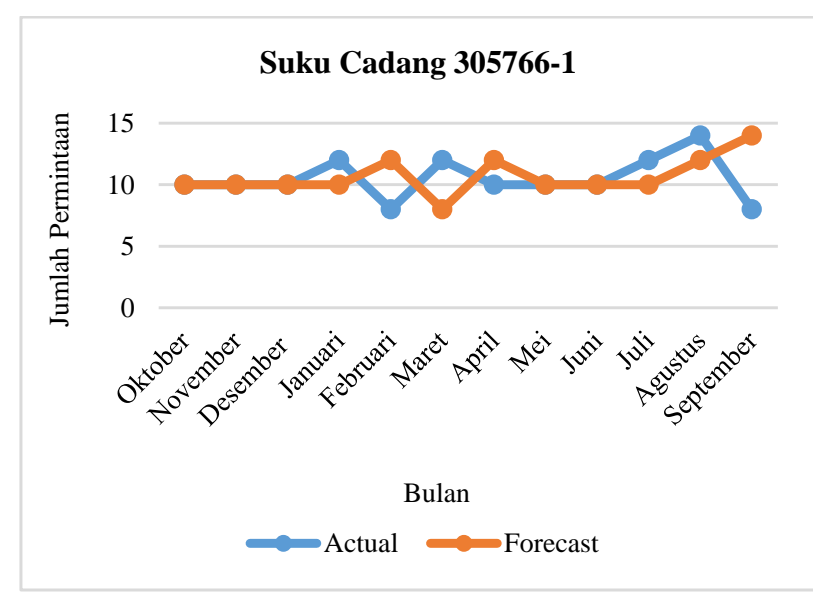

Gambar 4.4 Grafik Permintaan Aktual

dengan peramalan spare part 305766-1

Pada gambar diatas dapat dilihat bahwa hasil peramalan menunjukkan permintaan yang lebih stabil pada bulan Oktober, November, Desember, Januari, Juni, dan Juli. Hal ini berbeda dengan tahun sebelumnya dimana permintaan stabil hanya terjadi pada 5 bulan yaitu Oktober, November, Desember, Mei, dan Juni.

Hasil peramalan ini hampir mendekati data observasi yang dilakukan karena peramalan dilakukan dengan metode single exponential smoothing

\subsection{Analisis Periode Waktu Antar Pemesanan} (T)

Periode waktu antar pemesanan ( $T$ ) yang dihasilkan dari model periodic review untuk 5 suku cadang kelas A berbeda-beda. Perbedaan periode waktu antar pemesanan ( $T$ ) pada 5 suku cadang kelas A dapat dilihat pada sajian gambar 4.5.

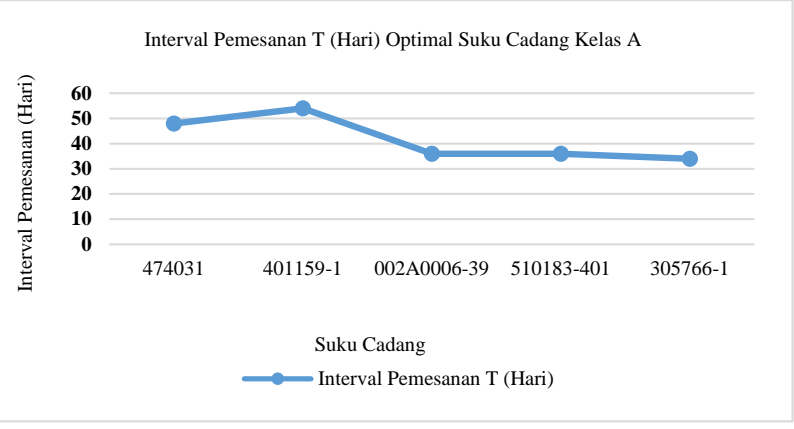

Gambar 4.5 Interval Pemesanan T (Hari)

Berdasarkan gambar diatas, dapat diketahui bahwa hasil perhitungan periode waktu antar pemesanan (T) pada setiap suku cadang kelas A berbeda-beda. Periode waktu antar pemesanan (T) paling pendek adalah 34 hari pada suku cadang 305766-1 dan yang paling panjang adalah 54 hari pada suku cadang 401159-1.

Pada suku cadang 305766, periode waktu antar pemesanan ( $T$ ) yang dihasilkan paling pendek hal ini dikarenakan permintaan suku cadang 305766 cukup tinggi yaitu 128 unit/tahun. Sedangkan, Pada suku cadang 401159-1 periode waktu antar pemesanan $(T)$ yang dihasilkan paling panjang hal ini dikarenakan permintaan suku cadang 401159-1 tidak begitu tinggi yaitu 50 unit/tahun. Adanya interval pemesanan tersebut untuk mengantisipasi terjadinya shortage dengan melakukan peninjauan setiap interval pemesanan.

\subsection{Analisis Perbandingan Persediaan Maksimum}

Pada metode min-max, pemenuhan persediaan hingga level maksimum dilakukan jika sudah mencapai titik pemesanan kembali (ROP). Sedangkan, pada model periodic review, pemenuhan persediaan hingga level maksimum dilakukan jika sudah sampai pada interval pemesanan yang sudah ditentukan.

Berikut adalah perbandingan persediaan maksimum metode min-max perusahaaan dengan model usulan periodic review untuk suku cadang kelas A dapat dilihat pada sajian gambar 4.6. 


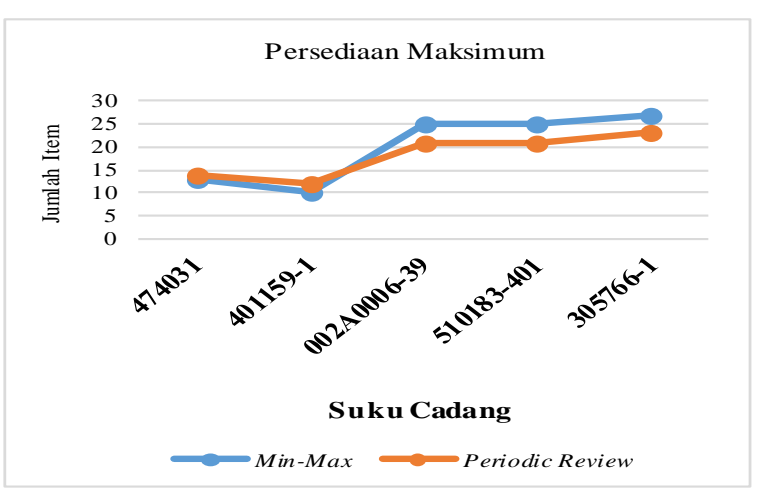

Gambar 4.6 Grafik Perbandingan Persediaan Maksimum

Berdasarkan gambar 4.6 diatas, maka dapat diketahui bahwa Perbedaan jumlah persediaan maksimum ini dikarenakan persediaan maksimum yang dihitung dengan menggunakan metode min-max hanya bergantung pada titik pemesanan kembali, minimum stok, dan leadtime. Sementara, model periodic review mempertimbangkan service level pada tabel distribusi normal, besarnya demand, interval pemesanan, dan lead time.

Persediaan maksimum yang diterapkan oleh perusahaan dengan metode min-max belum optimal dikarenakan masih sering terjadi shortage karena pemenuhan persediaan maksimum dilakukan jika mencapai titik pemesanan kembali. Sedangkan, persediaan model periodic review sangat optimal dalam menetapkan persediaan maksimum dikarenakan kemungkinan terjadinya shortage yaitu 0 karena pemenuhan persediaan maksimum dilakukan pada interval yang ditentukan, sehingga dapat meminimalkan shortage cost.

\subsection{Analisis Perbandingan Rata-Rata Persediaan di gudang}

Rata-rata persediaan digudang digunakan untuk mengetahui besarnya holding cost yang harus ditanggung oleh perusahaan selama kurun waktu 1 tahun. Berikut, hasil perbandingan rata-rata persediaan di gudang selama tahun 2017 dapat dilihat pada sajian gambar 4.7

Berdasarkan gambar 4.7, maka dapat diketahui bahwa hasil rata-rata persediaan yang dimiliki perusahaan selama digudang dengan menggunakan model periodic review memiliki jumlah yang lebih sedikit dibandingkan metode min-max. Hal ini disebabkan model periodic review Hasil rata-rata persediaan selama di gudang menggunakan metode min-max menunjukkan hasil yang lebih tinggi dibandingkan dengan model periodic review, hal ini dikarenakan perusahaan menyimpan persediaan sebanyak persediaan maksimum dikurangi permintaan selama leadtime.

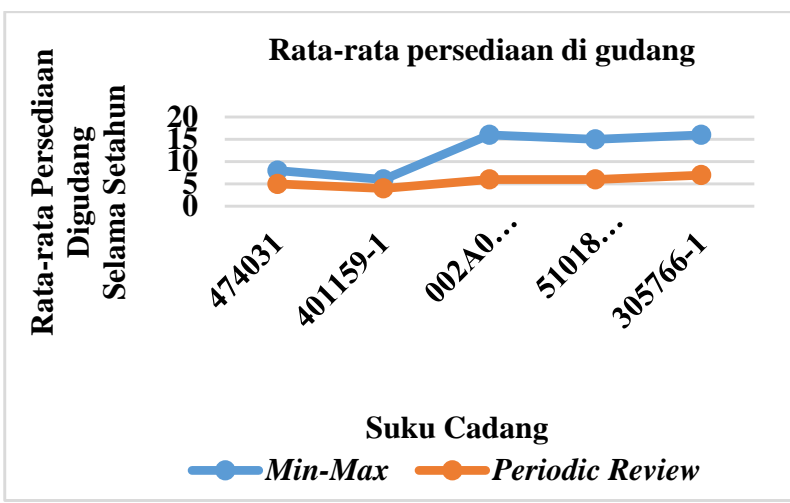

Gambar 4.7 Rata-Rata Perbandingan Persediaan di gudang selama setahun

Sedangkan model periodic review, memiliki persediaan yang sedikit dikarenakan tidak hanya mengurangkan persediaan maksimum dengan permintaan selama leadtime, melainkan ada faktor permintaan selama interval pemesanan.

Dengan meminimalisasi jumlah persediaan yang ada di gudang, akan mengurangi besarnya holding cost yang akan ditanggung oleh perusahaan karena jumlah persediaan rata-rata yang ada di gudang semakin sedikit.

\subsection{Analisis Perbandingan Total Biaya Persediaan}

Dapat diketahui bahwa total biaya persediaan perusahaan dengan metode min-max untuk 5 item suku cadang kelas A sebesar Rp 206,657,743.73. Sedangkan total biaya persediaan usulan dengan model periodic review untuk 5 item suku cadang kelas A sebesar Rp 125,535,907.12.

Hasil Perbandingan selisih total biaya persediaan per item dapat dilihat pada sajian gambar 4.8.

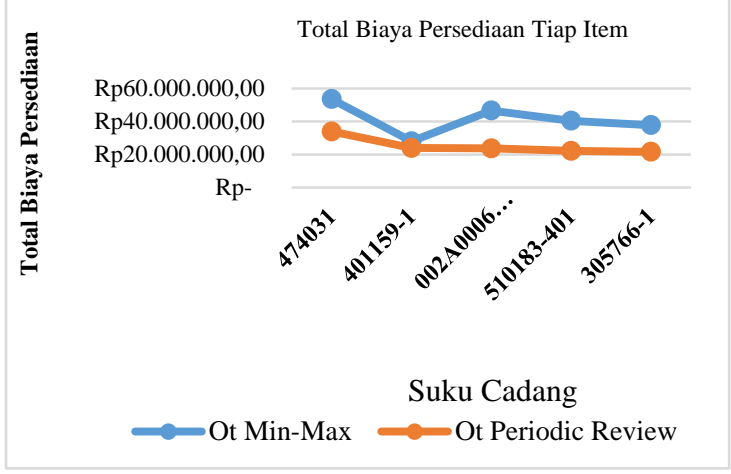

Gambar 4.8 Grafik Perbandingan Total Biaya Persediaan Tiap Item

Berdasarkan gambar 4.10 diatas maka dapat diketahui selisih Total Biaya Min-Max dengan Periodic Review untuk suku cadang 474031 yaitu Rp 19,653,070.40 dengan persentase selisih sebesar $36.63 \%$, untuk suku cadang 401159-1 selisih total biaya persediaan yaitu Rp 
4,048,674.64 dengan persentase selisih sebesar $14.44 \%$, untuk suku cadang 002A0006-39 selisih total biaya persediaan yaitu Rp 22,941,718.67 dengan persentase selisih sebesar 49.15\%, untuk suku cadang 510183-401 selisih total biaya persediaan yaitu Rp 18,307,438.11 dengan persentase selisih sebesar 45.21, untuk suku cadang 305766-1 selisih total biaya persediaan yaitu Rp 16,170,934.80.

Berdasarkan pada perhitungan sebelumnya, maka perbandingan total biaya persediaan keseluruhan 5 item suku cadang kelas A dapat dilihat pada sajian gambar 4.9

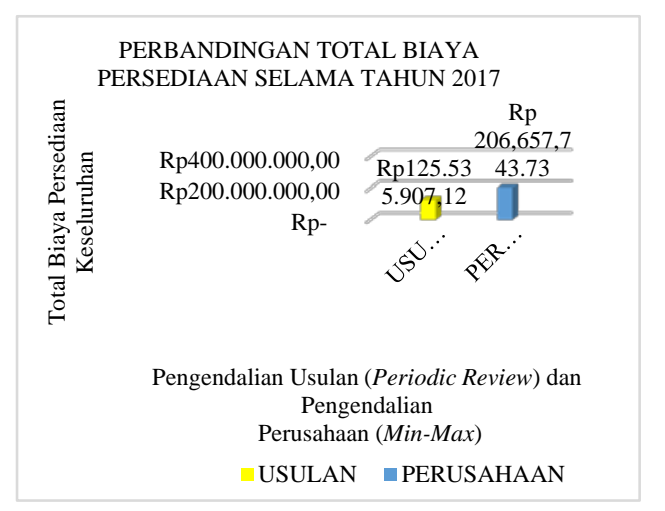

Gambar 4.9 Diagram Batang Perbandingan

Total Biaya Persediaan Keseluruhan Berdasarkan gambar 4.11 diatas, maka dapat diketahui total biaya persediaan model Periodic Review menghasilkan total biaya persediaan yang lebih kecil yaitu sebesar Rp 125,535,907.12. Sedangkan, total biaya persedian dengan menggunakan kebijakan perusahaan yaitu sebesar Rp 206, 657,743.73. Model periodic review yang dilakukan dapat menghemat total biaya persediaan yang dikeluarkan perusahaan untuk mengelola persediaan di PT. X. Besarnya penghematan yang diperoleh dari Model Periodic Review sebesar Rp 81,121,836.62. Sehingga persentase selisih total biaya persediaan yaitu sebesar 39.25\%.

Penghematan total biaya persediaan dipengaruhi oleh beberapa faktor, satu diantaranya adalah berkurangnya persediaan rata-rata semua suku cadang kelas A di gudang.

\section{SIMPULAN}

Dari hasil pengolahan data diperoleh kesimpulan sbb:

1) Jumlah suku cadang yang didapatkan untuk kelas A pada klasifikasi ABC yaitu sebanyak 5 item dengan persentase sebesar $12.5 \%$ dari total item keseluruhan sebanyak 40 item. Sedangkan, total harga suku cadang kelas A sebesar Rp 132,285,644.22 dengan persentase sebesar
71.81\% dari total harga keseluruhan sebesar Rp $184,218,274.36$.

2) Model periodic review yang telah digunakan dapat menghasilkan periode waktu antar pemesanan $(T)$ yang optimal untuk 5 suku cadang kelas A. Periode waktu antar pemesanan $(T)$ pada setiap suku cadang berbeda, periode waktu antar pemesanan $(T)$ paling pendek adalah 34 hari pada suku cadang 305766-1 dan yang paling lama adalah 54 hari pada suku cadang 401159-1.

3) Model periodic review yang telah digunakan dapat menghasilkan persediaan maksimum $(R)$ yang optimal untuk 5 suku cadang kelas A. Persediaan maksimum $(R)$ pada setiap suku cadang berbeda, persediaan maksimum $(R)$ paling sedikit adalah 12 unit pada suku cadang 401159-1 dan yang paling banyak adalah 23 unit pada suku cadang 305766-1.

4) Hasil perbandingan total biaya persediaan model periodic review dengan metode minmax yaitu total biaya persediaan model periodic review mempunyai nilai yang lebih kecil dibandingkan metode min-max dengan Selisih Total Biaya Persediaan yaitu sebesar Rp 81,121,836.62 dan persentase selisih total biaya persediaan yaitu sebesar $39.25 \%$.

\section{DAFTAR PUSTAKA}

Ahmad Jauhari, Wakhid. 2008. Penentuan Model Persediaan Spare Part Dengan Mempertimbangkan Terjadinya Back Order. Jurnal Gema Teknik - Nomor 1 / Tahun XI.

Akyati, Monica Bakhtyarthi. 2011. Pengendalian Persediaan Periodic Review. Surakarta : Jurnal UNS

Dirpan, Andi STP.2007.Metode Peramalan Kuantitatif. Makasar : Jurnal UNHAS.

Fatchur Rochman, Sayyidan. 2013. Penentuan Kebijakan Persediaan Spare Parts Pada Perusahaan Migas Dengan Pendekatan Simulasi Monte Carlo. Depok : Skripsi UI.

Gasperz, Vincent. 2007. Production Planning and Inventory Control. Jakarta : PT. Gramedia Pustaka Utama.

Herjanto, Edi. 2007. Manajemen Operasi Edisi Ketiga. Jakarta : Grasindo

Herjanto, Edi. 2009. Sains Manajemen : Analisis Kuantitatif Untuk Pengambilan Keputusan. Jakarta : Grasindo

Muhbiantie, Ranidya Tri Y. 2011. Pengendalian Persediaan Suku Cadang Pesawat Terbang Dengan Pendekatan Model Continous Review. Surakarta : Skripsi UNS. 
Team Material Expandable. 2016. Laporan Tahunan (Monitoring) B737-NG. Tangerang : PT.X

Wisner, Joel D. 2017. Operations Management : A Supply Chain Process Approach. California : SAGE.

https://id.wikipedia.org/wiki/Boeing_737 